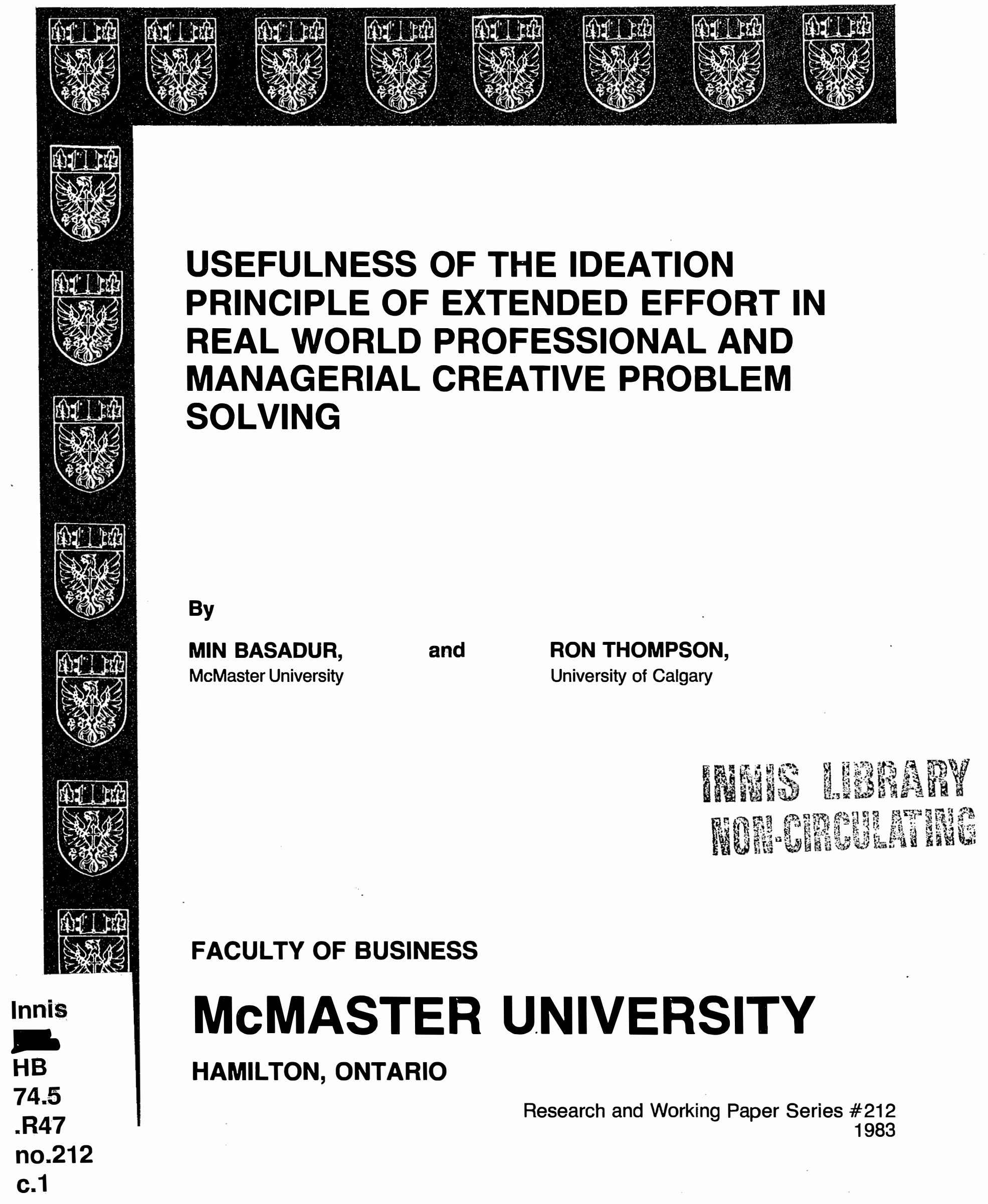




\title{
Usefulness of the Ideation Principle of Extended Effort in Real World Professional and Managerial Creative Problem Solving
}

\author{
Min Basadur \\ Ron Thompson \\ MaMaster University University of Calgary
}

Copyright 1983, Dr. Min Basadur and Mr. Ron Thompson 
This material is the property of $\mathrm{Dr}$. Min Basadur and $\mathrm{Mr}$. Ron Thompson and is for the sole and exclusive use of participants in their classes at McMaster University and in their conference presentations \& Seminars. It is not to be resold, reproduced or generally distributed.

"No part of this material is reprinted out of Copyright. Reproductions made with the permission of the copyright holder are acknowledged." 


\section{Abstract}

Two hypotheses relating to using the ideation principle of extended effort in idea generation to solve real world technical and managerial problems are tested in field research. In two studies involving training and application of a "complete process of creative problem solving" emphasizing the ideation-evaluation process, the "most preferred ideas" were well dispersed and furthermore were more likely to be found among the latter two thirds of the ideas listed serially than in the first third. This provides support for the usefulness of the extended effort principle. One study $(n=101)$ involved individual creative problem solving, while the other $(n=264)$ involved small groups. The data give rise to speculation that perhaps the more effort devoted to fact finding and problem definition prior to idea generation, the earlier in the list of ideas will the most preferred idea occur. 
The technique or principle of extended effort in idea generation in creative problem solving has been of interest to researchers for sometime. Extended effort is defined as striving to obtain as many ideas as possible (rather than stopping with the early ideas that come to mind) during idea generation. One statement attibuted to Linus Pauling that relates to extended effort is "the best way to have a good idea is to have lots of ideas" (Parnes, Noller, and Biondi 1977). Another saying, "quantity breeds quality", represents one of the four operational rules of the well known brainstorming technique (Osborn, 1963):

1) No criticism of ideas permitted - think up now, evaluate later

2) Quantity breeds quality - the more ideas the better (the greater the likelihood of a good one)

3) Freewheeling is welcome - the wilder the idea the better because it is easier to tame down wild ideas than to make dull ideas more novel, and

4) Hitchhiking is sought - add on to and combine previous ideas to make new ideas.

In addition, Gordon (1956) somewhat poetically describes the principle of 'deferment', referring to 'the capacity to discard the glittering immediate in favor of a shadowy but possibly richer future.' Gordon advocates not being content with earlier, more obvious ideas but, rather, extending effort for additional, potentially more valuable ideas.

The implications of these statements and theories are that the more ideas you have:

(i) the better your chances of coming up with a really good one and/or (ii) the more good ideas you will have and/or (iii) the higher the quality of the good ideas, and/or (iv) the 'best' idea will not necessarily come early in the 
chronologial series of ideas produced.

One further speculation, made by Parnes (1961), is that perhaps the best idea in a series of ideas is more likely to come later in the chronological series of ideas, the more ideas that are generated.

Since it is difficult to operationally define 'best' in this context, the term 'Most Preferred Idea', (MPI), is used throughout this paper to represent that idea which is chosen as the 'best' from a chronological list (or series) of ideas. The selection is always made by the person to whom the problem belongs.

Five general hypotheses that can be derived from the above theories and speculations follow. Three are based on the Pauling, Osborn, and Gordon statements, and two on Parnes. These five hypotheses are:

To solve problems requiring creativity, using extended effort during idea generation results in:

$\mathrm{H}_{1}:$ an increased quantity of good ideas in a given time period.

$\mathrm{H}_{2}$ : increasingly larger proportions of good ideas in a series of ideas.

$\mathrm{H}_{3}$ : higher quality ideas.

$\mathrm{H}_{4}$ : the Most Preferred Idea (M.P.I.) most often not occurring among the earliest ideas generated in a series of ideas.

$\mathrm{H}_{5}$ : the Most Preferred Idea (M.P.I.) most often occurring among the latest ideas generated in a series of ideas.

It should be noted that $\mathrm{H}_{4}$ and $\mathrm{H}_{5}$ are independent. There are ideas in a series which are neither among the earliest nor the latest. These would be the ideas in the middle of the serial list of ideas.

The first two general hypotheses, $\mathrm{H}_{1}$ and $\mathrm{H}_{n}$ have been supported in laboratory experimentation (Parnes \& Meadow, 1959, and Parnes, 1961; refer to Appendix I). The third general hypothesis, $\mathrm{H}_{3}$, has been supported in field experimentation (Basadur, Graen, \& Green, 1982, and Cohen, Whitmeyer and Funk, 
1960). It should be noted that Rickards, 1975, reported field research which did not support $\mathrm{H}_{3}$, but as discussed more completely by Basadur (1979), this may have been due to an insufficiently short training period prior to idea generation. Both Basadur, et al, and Cohen, et al, used much longer training periods than Rickards when testing $\mathrm{H}_{3}$. They found that higher quality ideas were produced by managers and professionals trained in using extended effort in solving real world problems than their untrained counter parts.

The fourth and fifth general hypotheses, $\mathrm{H}_{4}$ and $\mathrm{H}_{5}$, have not yet been tested in either the laboratory or field. The present study is designed to fill this gap. It tests hypotheses $\mathrm{H}_{4}$ and $\mathrm{H}_{5}$ on meaningful, real world managerial and professional problems using subjects trained in extended effort. The hypotheses tested in this field research are specifically worded as follows:

In creative problem solving, when extended effort is used to generate a series of ideas to solve a meaningful real world technical or managerial problem, the most preferred idea:

$\mathrm{H}_{4}$ : most often will not occur among the earliest ideas in the series and $\mathrm{H}_{5}$ : most often will occur among the latest ideas in the series.

Method

Two separate studies were conducted to test the above hypotheses. Both studies involved training in creative problem solving based on a two step thinking process called ideation-evaluation. As described more fully by Basadur, Graen and Green (1982) and Basadur and Finkbeiner (Notes 1 and 2) this is a two step process during which two fundamental kinds of thinking are separated and employed in sequence. The first is ideation, the generation of ideas without judgment; the second is evaluation, the application of judgment to the ideas generated. The use of this process involves both cognitive and related attitudinal skills which it is believed can be developed by 
sufficiently in depth training. Extended effort is one such skill. For example, brainstorming is one specific technique of ideation and includes extended effort. There are many other individual and group ideation techniques.

In the first study, managers and professionals were trained for $1 / 2$ day (4 hours) and then applied their training individually to a problem that was common to all of them. They used the above ideation-evaluation thinking process within a larger thinking process called a "complete process of creative problem solving." This "complete process" is described in Basadur (1982) and Basadur, Graen \& Green (1982). In this "complete process," three steps, problem finding, fact finding and problem definition, precede the idea generation step. Furthermore, after the idea generation step, four additional steps relațing to idea evaluation, selection and implementation follow. Each such step contains the two step ideation - evaluation process within it. Participants devoted 5 minutes to each of the three steps preceeding idea generation (total 15 minutes). They shared their work at the end of each step. At the end of the third step one common problem definition was selected as useful and meaningful to everyone. The idea generation step was then done individually for 5 minutes on this common problem definition. Individuals then chose their most preferred idea (M.P.I.) from the series of ideas (list) they had just generated. No formal evaluation criteria were used. The total number of ideas in the series and the chronological or serial position in the series of the most preferred idea (M.P.I.) were reported by each individual.

In the second study, managers and professionals were trained for one or two days (8 to 16 hours) in the same "complete process of creative problem solving" described above and applied it to their own individual problems from the beginning. (There was no common agreed problem). Each individual received help from a small group comprised of three other trainees. The four 
individuals worked as a group, helping each other in turn through each step of the "complete process". Thus, in the idea generation step, each group of four participants did group idea generation for 10 minutes for each individual's problem in turn after having already invested about two hours in the problem finding, fact finding and problem definition steps for each individual. Again, each of these three steps preceding the idea generation step included the ideation-evaluation process, permitting individuals to look at their problem in a variety of different ways before selecting a final problem definition. Later each group developed a list of potential criteria for idea evaluation. Individuals chose the most preferred idea (M.P.I.) individually from the list generated for their problem definition using their own criteria selected from the list of potential criteria. This was step 5 in the "complete process". As in the first study above, individuals then reported their total number of ideas in the series and the chronological (serial) position in the series of the most preferred idea (M.P.I.).

\section{SAMPLE}

The participants were managers and professionals drawn from a variety of organizations. They represented varied jobs including nursing and hospital administrators; managers, supervisors, engineers, technicians and other professionals from various industrial and business organizations, and managers, scientists and engineers doing government military research and development work. All participants were at the training sessions because their organizations wanted them to increase their creative problem solving performance on the job. The training was done in "family" groups, that is, each training group came from the same organization.

The base size in the first study was 101, and 264 in the second. The training groups involved 10 to 30 participants each. There were 6 training groups in the first study, and 14 in the second. 


\section{ANALYSIS}

The data for both studies were analysed by tabulating how frequently the most preferred idea (M.P.I.) occurred in the first third, middle third, and last third of the serial list of ideas generated for each problem. This analysis follows Parnes' approach (1961). The data collection procedure is described in Appendix II. Then the hypotheses were tested as follows:

- $\mathrm{H}_{4}$ was tested by calculating if significantly more of ten the most preferred idea (M.P.I.) was to be found in the latter two thirds of the ideas listed serially rather than the first third.

- $\mathrm{H}_{5}$ was tested by calculating if significantly more of ten the most preferred idea (M.P.I.) was to be found in the last third of the ideas listed serially rather than the first two thirds.

In addition, in the second study only, the data were also analysed by using the four most preferred ideas rather than the single most preferred idea, and $\mathrm{H}_{4}$ and $\mathrm{H}_{5}$ were tested again accordingly. These data were not available from the first study because the idea lists were not sufficiently long to permit four ideas to be selected as "most preferred" in a meaningful way.

Thus there were three comparisons testing each of the two hypotheses. The statistical test employed was the non-parametric z-test for proportions. The proportion chosen for testing was 508; for example, if in testing $\mathrm{H}_{5}$ greater than $50 \%$ of the most preferred ideas chosen were from the last third of the ideas listed serially, it would be considered significant.

\section{Results}

The frequency distribution of the location of the Most Preferred Idea (M.P.I.) by the third (serially) of the idea list in which it occurred as a percentage of the total number of panelists (idea lists) is displayed for both studies in Tables 1 and 2. The analogous data for the four Most Preferred 
Ideas in study \#2 are shown in Table 3. The results of the corresponding tests of significance are included in the same tables.

The same results are displayed graphically in Tables 4,5 , and 6 .

TABLE 1

Results For Study \#1

\begin{tabular}{|c|c|c|}
\hline \multicolumn{3}{|c|}{$\begin{array}{l}\text { Frequency of Occurrence of the } \\
\text { Most Preferred Idea (M.P.I.) within the }\end{array}$} \\
\hline$\frac{\text { First Third }}{40(39.6 \%)}$ & $\frac{\text { Middle Third }}{26(29.78)}$ & $\frac{\text { Last }}{35(34.78)}$ \\
\hline$\frac{\text { First Third }}{40(39.6 \%)}$ & \multicolumn{2}{|c|}{$\frac{\text { Latter }}{61} \frac{\text { Two }}{(60 .} \frac{\text { Thirds }}{48)}$} \\
\hline \multicolumn{2}{|c|}{$\frac{\text { First }}{66} \frac{\text { Two Thirds }}{(65.38)}$} & $\frac{\text { Last }}{35} \frac{\text { Third }}{(34.78)}$ \\
\hline
\end{tabular}

Tests of Statistical Significance (alpha $=.05)$ :

(For Significance, $\mathrm{Z}>\mathrm{Z}_{.05}=1.96$ )

Testing $\mathrm{H}_{4}$ : Latter two thirds

$* \mathrm{z}=2.09 \quad(\mathrm{p}=.04)$

First third

Testing $\mathrm{H}_{5}$ : Last third

vs.

$\mathrm{Z}=-3.08 \quad$ (n.s.)

First two thirds

$=======$

First two thirds

* denotes statistically significant at $p<.05$ 
TABLE 2

Results For Study \#2 = Single Most Preferred Idea

\begin{tabular}{|c|c|c|}
\hline \multicolumn{3}{|c|}{$\begin{array}{l}\text { Frequency of Occurrence of the } \\
\text { Most Preferred Idea (M.P.I.) within the: }\end{array}$} \\
\hline$\frac{\text { First }}{118(4 h i r d}$ & $\frac{\text { Middle }}{83(31.48)}$ & $\frac{\text { Last Third }}{63(23.98)}$ \\
\hline$\frac{\text { First }}{118(44.78)}$ & \multicolumn{2}{|c|}{$\frac{\text { Latter }}{146} \cdot \frac{\text { Two }}{(55.3 \mathrm{~s})}$} \\
\hline \multicolumn{2}{|c|}{$\frac{\text { First Two Thirds }}{201} \frac{\text { Th }}{(76.18)}$} & $\frac{\text { Last }}{63} \frac{\text { Third }}{(23.98)}$ \\
\hline
\end{tabular}

Tests of Statistical Significance (alpha $=.05$ )

(For Significance, Z $>$ Z $.05=1.96$ )

Testing $\mathrm{H}_{4}:$ Latter two thirds
vs.
First third

Testing $\mathrm{H}_{5}$ : Last third

vs.

First two thirds
$\mathrm{Z}=1.723 \quad(\mathrm{n} . \mathrm{s} ., \mathrm{p}=.08)$

=ニニニ=ニ

$$
\mathrm{Z}=-8.493 \quad \text { (n.s.) }
$$

ニニニニニ 
$\underline{\text { TABLE }} 3$

Results For Study \#2 - Among the Four Most Preferred Ideas

\begin{tabular}{|c|c|c|}
\hline $\begin{array}{r}\text { Frequenc } \\
\text { Most Prefer }\end{array}$ & $\begin{array}{c}\text { Eccurrence of } \\
\text { Ideas (M.P.I.) }\end{array}$ & $\begin{array}{l}\text { the Four } \\
\text { within the: }\end{array}$ \\
\hline$\frac{\text { First Third }}{451(42.7 \%)}$ & $\frac{\text { Middle }}{353(33.48)}$ & $\frac{\text { Last Third }}{252(23.98)}$ \\
\hline$\frac{\text { First Third }}{451(42.78)}$ & $\frac{\text { Latter }}{605}$ & $\frac{\text { (wo Thirds }}{(57.38)}$ \\
\hline \multicolumn{2}{|c|}{$\frac{\text { First }}{804} \frac{\text { Two Thirds }}{(76 . \overline{18)}}$} & $\frac{\text { Last Third }}{252} \frac{\text { This }}{(23.9 \%)}$ \\
\hline
\end{tabular}

Tests of Statistical Significance (alpha $=.05$ )

(For Significance, $\mathrm{Z}>\mathrm{Z} .05=1.96$ )

Testing $\mathrm{H}_{4}:$ Latter two thirds

$\star \star Z=5.231 \quad(p<.001)$

First third

Testing $\mathrm{H}_{5}$ : Last third

$Z=-16.988$ (n.s.)

vs.

=ニニニニ=

First two thirds

** denotes statistically significant at $p<.001$ 
TABLE 4

Serial Position of Most Preferred Idea = Study \#I

By Thirds

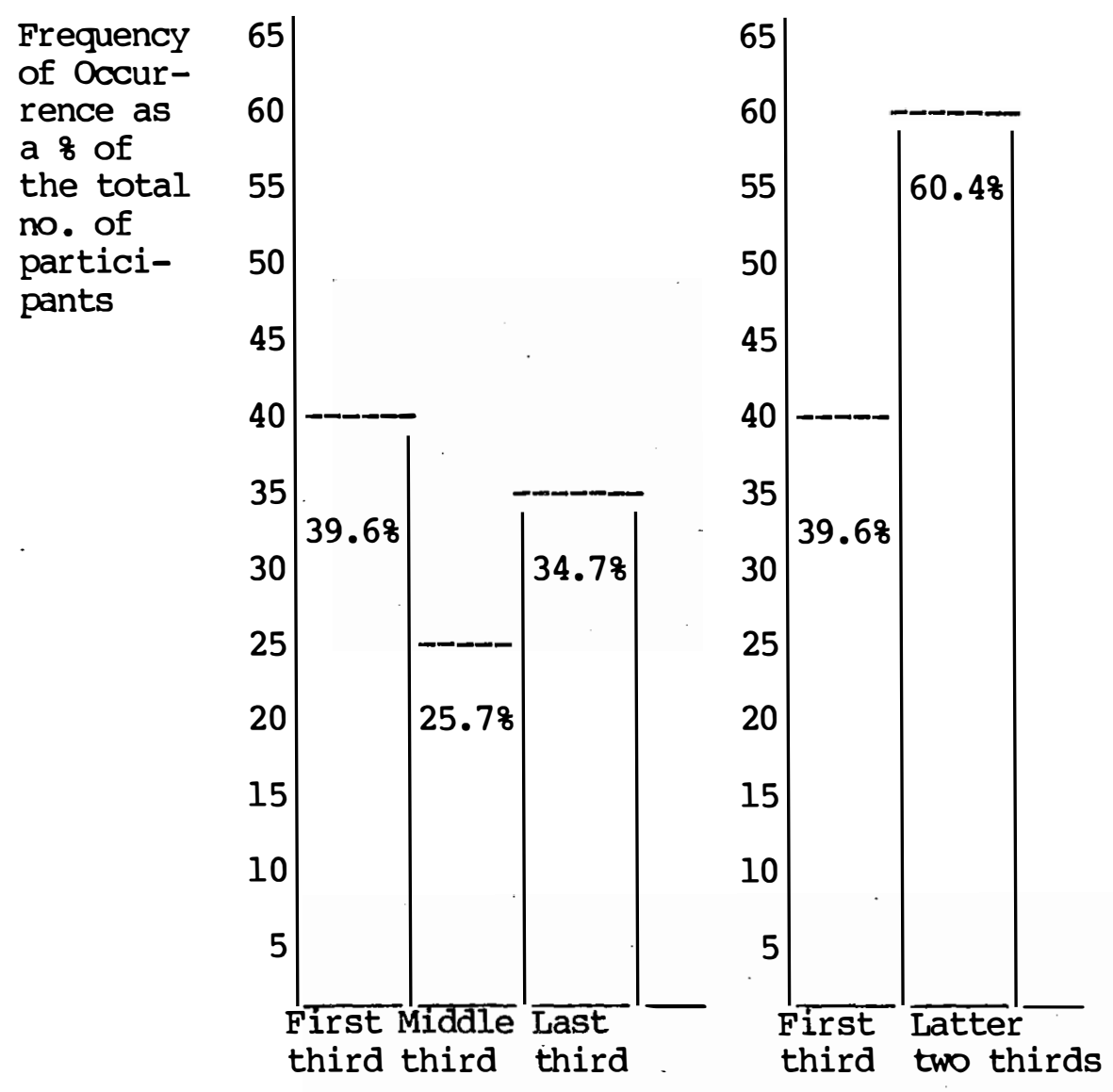

Testing $\mathrm{H}_{5}$

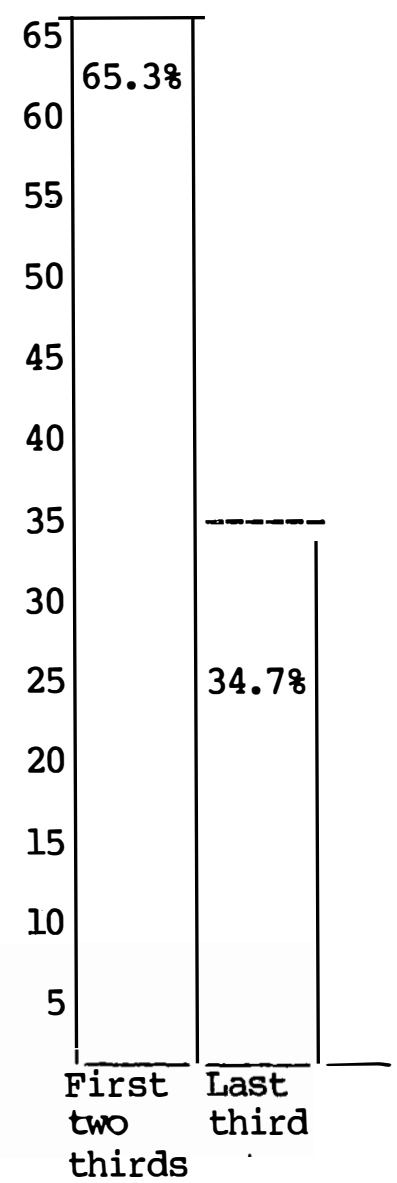

Serial Location of Most Preferred Idea Within the Idea List (i.e., - "In which third (serially) of the participant's idea list did the M.P.I. occur?") 
TABLE 5

Serial Position of Single Most Preferred Idea = Study \#2

By Thirds

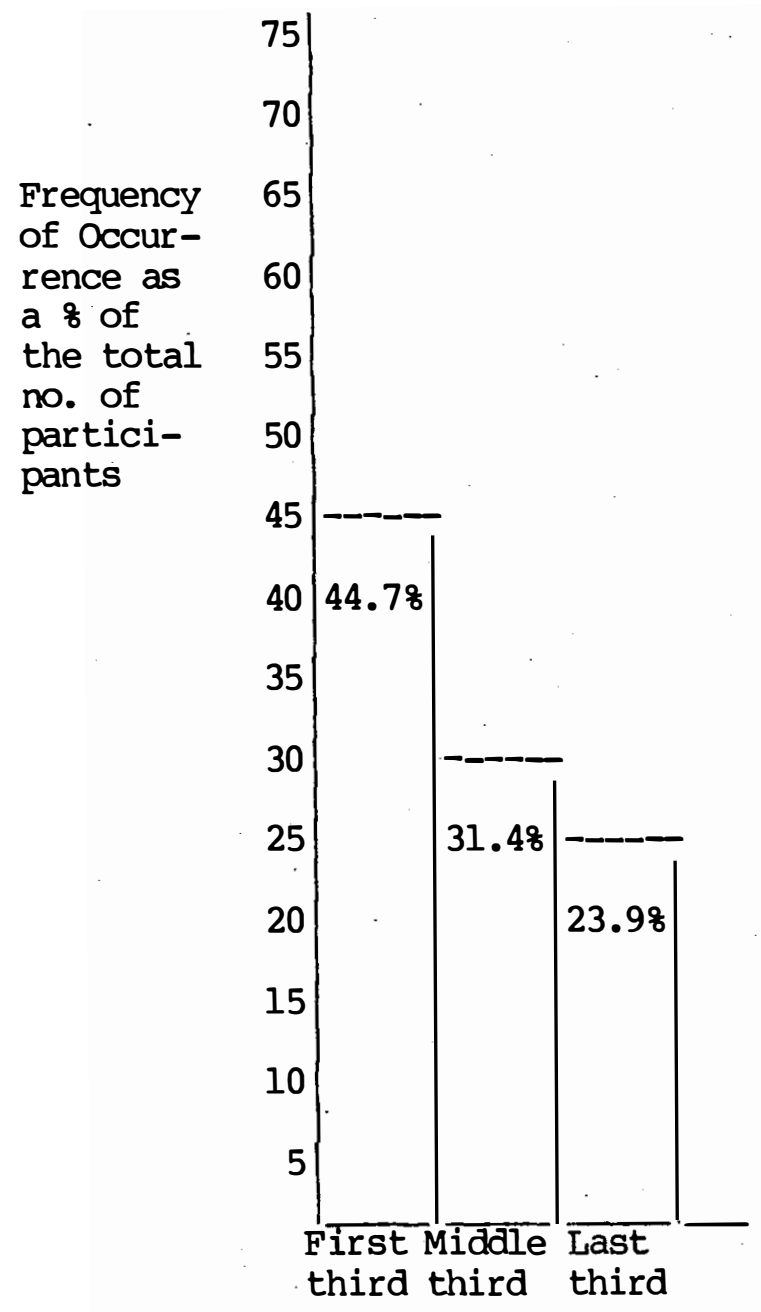

Testing $\mathrm{H}_{4}$

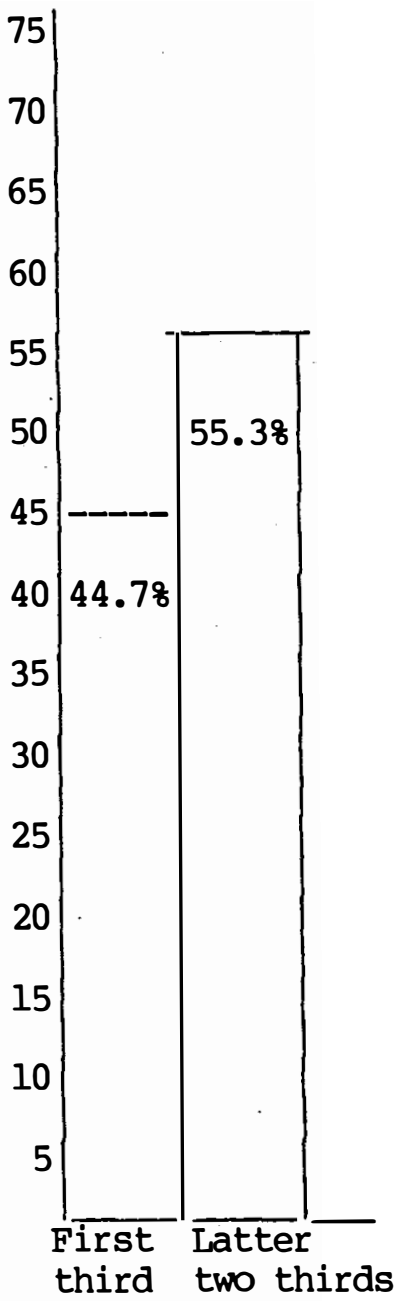

Testing $\mathrm{H}_{5}$

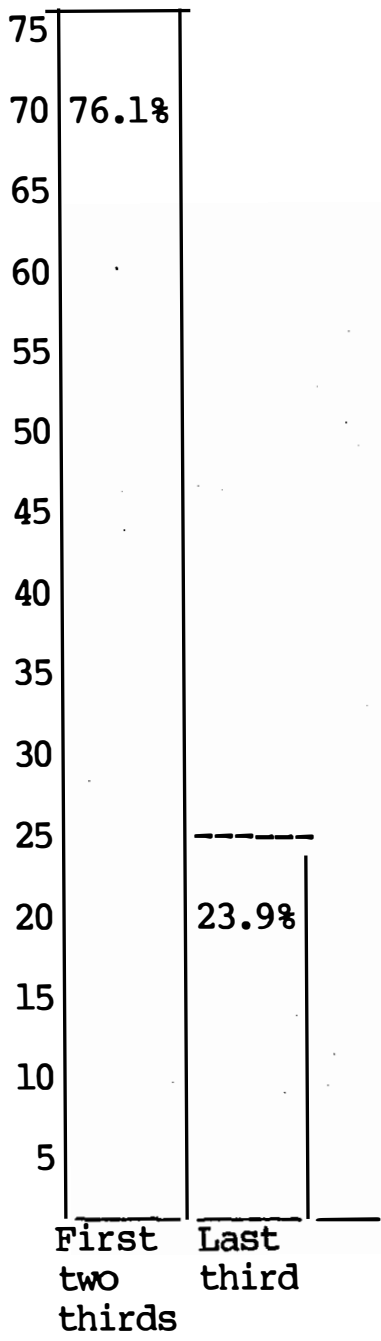

Serial Location of Most Preferred Idea Within the Idea List (i.e., - "In which third (serially) of the participant's idea list did the M.P.I. occur?") 
TABLE 6

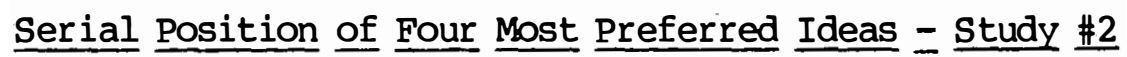

By Thirds

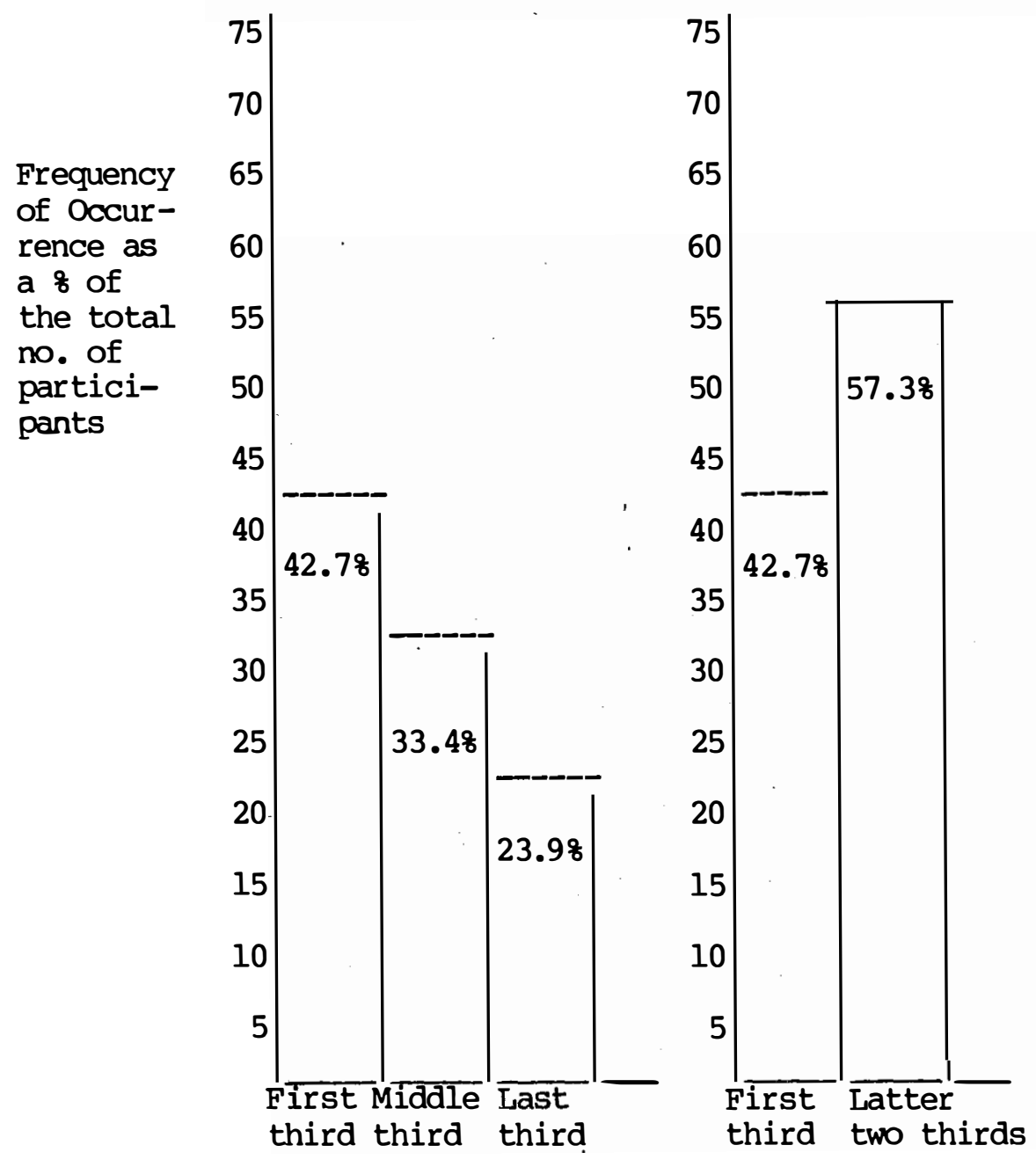

Testing $\mathrm{H}_{5}$

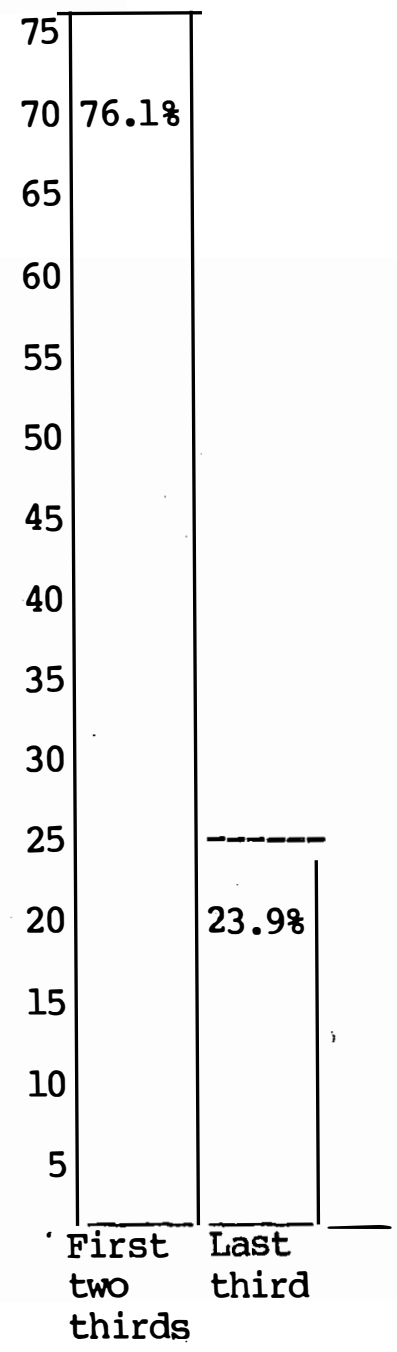

Serial Location of the Most Preferred Ideas Within the Idea List (i.e., - "In which third (serially) of the participant's idea list did each of the four M.P.I. occur?") 
In summary, in Study \#1, 39.68 of the participants chose their Most Preferred Idea from the first third of their serial list of ideas, while 25.78 chose them from the middle third, and 34.78 from the last third. For the tests of hypothesis, this meant that 39.68 chose their MPI from the first third and 60.48 from the latter two thirds. Conversely, 65.38 chose it from the first two thirds, and 34.78 from the last third.

The corresponding results for the Single Most Preferred Idea in Study \#2 were 44.78 from the first third, 31.48 for the middle third, and 23.98 for the last third. Thus, 44.78 chose their MPI from the first third, versus 55.38 for the latter two thirds, and 76.18 chose from the first two thirds, versus 23.98 for the last third.

Also in Study \#2,42.78 of the four Most Preferred Ideas came from the first third, 33.48 from the middle third, and 23.98 from the last third. Combining these for the test of hypotheses, 42.78 were chosen from the first third, and 57.38 from the latter two thirds, while 76.18 chose from the first two thirds, and 23.98 from the last third.

Discussion

Table 7 displays a summary of the hypothesis testing. In both studies, there is firm support for $\mathrm{H}_{4}$. In all three comparisons, the frequency of occurrence of the Most Preferred Idea(s) in the latter two thirds was higher than for the first third. In two of the three comparisons the difference was statistically significant.

Neither study provides any support for $\mathrm{H}_{5}$. In none of the three comparisons was the frequency of occurrence of the Most Preferred Idea(s) in the last third higher than the first two thirds. 
Table 7

Summary of Hypothesis Testing Results

\begin{tabular}{l|ccc|}
\hline & $\begin{array}{c}\text { Study \#I } \\
\text { (Single M.P.I.) }\end{array}$ & $\begin{array}{c}\text { Study \#2 } \\
\text { (Single M.P.I.) }\end{array}$ & $\begin{array}{c}\text { Study \#2 } \\
\text { (Four M.P.I.'s) }\end{array}$ \\
\hline Support for $\mathrm{H}_{4}$ & $\begin{array}{c}\text { Yes } \\
(\mathrm{p}=.04)\end{array}$ & $\begin{array}{c}\text { No } \\
(\mathrm{p}=.08)\end{array}$ & $\begin{array}{c}\text { Yes } \\
(\mathrm{p}<.001)\end{array}$ \\
\hline Support for $\mathrm{H}_{5}$ & No & No & No \\
\hline
\end{tabular}


Additionally, the overall dispersion of the Most Preferred Idea in the two studies is important to note. In study \#1, the frequency of occurrence of the Most Preferred Idea was somewhat uniform (the last third was similar to the first third, with middle third somewhat lower than either). In Study \#2, although there was evidence of a gradual decline from the first to the last third, there.was still a substantial representation in the last third, and there were more MPI's in the latter two thirds than the first third. In summary, the Most Preferred Idea was generally well dispersed among the total list of ideas overall in both studies.

The above results lead the authors to conclude that the belief that extended effort is useful in creative problem solving is supported for real world managerial and technical problem solving in this study. While it does not appear that the most preferred ideas are more likely to come more often at the very end than at the very beginning of the idea series, nevertheless, it does appear that the they are likely to occur more often than not after the first early burst of ideas. At the very least, both studies indicate a substantial dispersion of the most preferred ideas throughout the serial list.

\section{Future Directions}

The apparent pattern difference between the two studies wherein there is some evidence of more of a downward trend in study \#2 in frequency of occurrence of the most preferred idea with serial position may be important to consider. Further; a very interesting future research direction would be to explore the reasons for the difference in pattern noted. For example, the possible causes of the difference may have to do with any or all of the following:

1) group vs. individual idea generation ("nominal group" effect? See Taylor, Berry, and Block, 1958)

2) duration of training (4 hours vs. 8-16 hours) 
3) length of time of idea generation (5 min. vs. $10 \mathrm{~min}$ )

4) greater use of a "complete process of creative problem solving," that is, more time spent on problem finding, fact finding and problem definition before idea generation ( 2 hours vs. $15 \mathrm{~min}$.)

For the authors, possibility \# 4 above is perhaps the most intriguing. The literature attributes the following sayings to John Dewey and Albert Einstein respectively: "a problem well-stated is half solved," and "the formulation of a problem is much more important than its solution", (Parnes, Noller and Biondi, 1977). Einstein is further quoted as saying if he were asked to solve a problem of world wide importance (to save the world) in only one hour, he would spend the first 55 minutes defining the problem and the last 5 minutes solving it. Thus, is it possible that the Most Preferred Idea should come earlier when significantly more attention is paid to developing a good problem definition? This would lead to research testing the hypothesis such as "the greater the time/effort devoted to defining the problem using a complete process of problem solving, the earlier the occurrence of the most preferred idea in a serial list of ideas."

Summary

Overall, the results of this study are consistent with the previous research in supporting the usefulness of the extended effort principle in training and application of processes of creative problem solving. In particular, these results indicate it is worthwhile for an individual or a group to use ideation when generating ideas on real world managerial and technical problems. The most preferred idea is likely to be dispersed anywhere throughout the idea list in idea generation sessions about 5-10 minutes in length. Significantly more people will find their most preferred idea in the latter two thirds of their idea list than in the first third. Thus, "quitting early" in idea generation reduces the chances of obtaining the idea that would be most preferred if given the opportunity to surface. 
Thus, in summary, Parnes, and Meadow and Parnes, found that extending effort provides significantly more good ideas in a given time period. Cohen, Whitneyer and Funk, and Basadur, Graen and Green found better ideas results from extended effort in a given time period. In this study, we have found that extending effort significantly increases the odds of finding a more preferred idea than the early ideas in a given time period. All of these findings suggest that quality and quantity are related positively in idea generation when the ideation principle is employed. 
$\underline{\text { Reference Notes }}$

1. Basadur, M.S., and Finkbeiner, C.T., "Identifying Attitudinal Factors Related to Ideation in Creative Problem Solving," Paper presented to 1983 American Psychological Association Convention, Anaheim, CA.

2. Basadur, M.S., and Finkbeiner, C.T., "Measuring Preference for Ideation in Creative Problem Solving," Working Paper \#208, McMaster University, Faculty of Business, July, 1983.

\section{References}

Basadur, M.S., Training in Creative Problem Solving: Effects on Deferred Judgment and Problem Finding and Solving in an Industrial Research Organization. Doctoral Dissertation, University of Cincinnati, $\overline{1979 .}$

Basadur, M.S., "Research in Creative Problem Solving Training in Business and Industry," Proceedings, Creativity Week 4, Center For Creative Leadership, 1982, Greensboro, N.C.

Basadur, M.S., Graen, G.B., Green, S.G., "Training in Creative Problem Solving: Effects on Ideation and Problem Finding and Solving in an Industrial Research Organization," Organizational Behavior and Human Performance, 1982, 30, 41-70.

Cohen, D., Whitmeyer, J.W., \& Funk, W.H., "Effect of Group Cohesiveness and Training upon Creative Thinking," Journal of Applied Psychology, 44(5), 1960.

Gordon, W.J.J., "Operational Approach to Creativity," Harvard Business Review, 1956,34 , No. 6, 41-51.

Meadow, A., Parnes, S.J.; and Reese, H., "Influence of Instructions and Problem Sequence on a Creative Problem Solving Test," Journal of Applied Psychology, 43 No. 6, 1959 .

Osborn, A.F., Applied Imagination, Charles Scribner's Sons, New York, New York, 1963.

Parnes, S.J., "Effects of Extended Effort in Creative Problem Solving," Journal of Educational Psychology, 1961, 52, No. 3.

Parnes, S.J., and Meadow, A., "Effects of 'Brainstorming Instructions on Creative Problem Solving by Trained and Untrained Subjects'," Journal of Educational Psychology 1959, 50, No. 4.

Parnes, S.J., Noller, R.B., and Biondi, A.M., Guide to Creative Action, Charles Scribner's Sons, New York, New York, 1977.

Rickards, T., "Brainstorming: An Examination of Idea Production Rate and Level of Speculation in Real Managerial Situations," $R_{\bullet} \underline{\&} D_{0}$ Management, $1975,6(1)$.

Taylor, D.W., Berry, P.C., and Block, C.H., "Does Group Participation When Using Brainstorming Facilitate or Inhibit Creative Thinking?" Adninistrative Science Quarterly, 1958, 3, pp. 23-47. 


\section{$\underline{\text { APPENDIX I }}$}

Parnes \& Meadow (1959) conducted a laboratory experiment which supported $\mathrm{H}_{1}$. They found a positive correlation between the number of ideas and the number of good ideas (ie. the more ideas generated the more good ideas). More specifically, they found that when subjects used either brainstorming or nonbrainstorming (see below) instructions to list all possible uses for an ordinary wire coat hanger or for an ordinary broom in a given time period, there was a significant correlation between the number of good ideas and the total quantity of ideas. In other words, subjects who generated significantly more ideas were also likely to have significantly more good ideas. Correlations were in the 0.64 to 0.81 range. (An independent rater judged the ideas for uniqueness and value/usefulness; non-brainstorming instructions were, for example, "list only good ideas, you'll be penalized for bad ideas").

Parnes (1961) conducted a laboratory experiment which supported $\mathrm{H}_{2}$ • A positive relationship was found between the number of ideas and the proportion of good ideas as follows. Parnes found that when asked to list uses for an ordinary wire coat hanger, untrained subjects had significantly more of their good ideas in the second half of their quantity of ideas than in the first half, and trained subjects had significantly more of their good ideas in the last third of their ideas than in either the first or middle third. (Although not statistically significant, there was also a slightly larger number of good ideas in the second third than the first third). Ideas were judged by an independent rater for uniqueness and value/usefulness. Although not statistically significant, there was also a slightly larger number of good ideas in the second third than the first third. Parnes concluded that these two experiments supported a trend towards increasingly larger proportions of good ideas with increased quantity of ideas. 
Based on these two laboratory experiments above, Parnes (1961) concluded that extended effort in creative problem solving is useful in that it leads to more good ideas and a greater proportion of good ideas on these kinds of (nonreal world) problems. 


\section{APPENDIX II}

Design and Measures

The research design is a field study in which the data are gathered by simple questionnaire following the problem solving activity. Each participant reported three numbers:

(1) the total number of ideas that were generated for the problem selected

(2) the chronological numbers (serial position) of their four Most Preferred Ideas (M.P.I.'s) generated

(3) the chronological number (serial position) of their single Most Preferred Idea (M.P.I.) generated.

The quantity of ideas generated and the serial position of the ideas selected were calculated by simple counting from the chart pads and notebooks used for recording the ideas. The counting occurred after the ideas had been generated and evaluated.

The quality of the ideas generated was measured by having each individual evaluate his or her own ideas as described elsewhere in this report.

For completeness of data and for other research purposes beyond the scope of this study, each participant also reported

(1) a statement of the selected problem as it was worded at the beginning of the problem solving activity and,

(2) a statement of how the problem was finally defined just prior to idea generation.

An example of one participant's questionnaire report is provided here:

1. Problem as Stated at Beginning of Process (Problem Finding) "The jet fuel Thermal Oxidation Tester does not give consistent results." 
2. Problem Definition Selected:

"How might I thermally stress the jet fuel without the Thermal

Oxidation Tester and still obtain consistent data results?"

3. Total number of ideas generated: 16

4. Four Best ideas: \#'s 3,4,15 and 16

5. Single Best Idea: \#15 


\author{
Faculty of Business \\ McMaster University \\ WORKING PAPER SERIES
}

101. Torrance, George W., "A Generalized Cost-effectiveness Model for the Evaluation of Health Programs," November, 1970.

102. Isbester, A. Fraser and Sandra C. Castle, "Teachers and Collective Bargaining in Ontario: A Means to What End?" November, 1971.

103. Thomas, Arthur L., "Transfer Prices of the Multinational Firm: When Will They be Arbitrary?" (Reprinted from: Abacus, Vol. 7, No. 1, June, 1971).

104. Szendrovits, Andrew Z., "An Economic Production Quantity Model with Holding Time and Costs of Work-in-process Inventory," March, 1974.

111. Basu, S., "Investment Performance of Common Stocks in Relation to their Price-earnings Ratios: A Text of the Efficient Market Hypothesis," March, 1975.

112. Truscott, William G., "Some Dynamic Extensions of a Discrete LocationAllocation Problem," March, 1976.

113. Basu, S. and J.R. Hanna, "Accounting for Changes in the General Purchasing Power of Money: The Impact on Financial Statements of Canadian Corporations for the Period 1967-74," April 1976. (Reprinted from Cost and Management, January-February, 1976).

114. Deal, K.R., "Verification of the Theoretical Consistency of a Differential Game in Advertising," March, 1976.

114a. Deal, K.R., "Optimizing Advertising Expenditures in a Dynamic Duopoly," March, 1976.

115. Adams, Roy J., "The Canada-United States Labour Link Under Stress," [1976].

116. Thomas, Arthur L., "The Extended Approach to Joint-Cost Allocation: Relaxation of Simplifying Assumptions," June, 1976.

117. Adams, Roy J. and C.H. Rumme1, "Worker's Participation in Management in West Germany: Impact on the Work, the Enterprise and the Trade Unions," September, 1976.

118. Szendrovits, Andrew Z., "A Comment on 'Optimal and System Myopic Policies for Multi-echelon Production/Inventory Assembly Systems'," [1976].

119. Meadows, Ian S.G., "Organic Structure and Innovation in Small Work Groups," October, 1976. 
120. Basu, S., "The Effect of Earnings Yield on Assessments of the Association Between Annual Accounting Income Numbers and Security Prices," October, 1976.

121. Agarwal, Naresh C., "Labour Supply Behaviour of Married Women - A Model with Permanent and Transitory Variables," October, 1976.

122. Meadows, Ian S.G., "Organic Structure, Satisfaction and Personality," October, 1976.

123. Banting, Peter M., "Customer Service in Industrial Marketing: A Comparative Study," October, 1976. (Reprinted from: European Journal of Marketing, Vo1. 10, No. 3, Summer, 1976).

124. Aivazian, V., "On the Comparative-Statics of Asset Demand," August, 1976.

125. Aivazian, V., "Contamination by Risk Reconsidered," October, 1976.

126. Szendrovits, Andrew Z. and George 0. Wesolowsky, "Variation in Optimizing Serial Multi-State Production/Inventory Systems, March, 1977.

127. Agarwal, Naresh C., "Size-Structure Relationship: A Further Elaboration," March, 1977.

128. Jain, Harish C., "Minority Workers, the Structure of Labour Markets and Anti-Discrimination Legislation," March, 1977.

129. Adams, Roy J., "Employer Solidarity," March, 1977.

130. Gould, Lawrence I. and Stanley N. Laiken, "The Effect of Income Taxation and Investment Priorities: The RRSP," March, 1977.

131. Callen, Jeffrey L., "Financial Cost Allocations: A Game-Theoretic Approach," March, 1977.

132. Jain, Harish C., "Race and Sex Discrimination Legislation in North America and Britain: Some Lessons for Canada," May, 1977.

133. Hayashi, Kichiro. "Corporate Planning Practices in Japanese Multinationals." Accepted for publication in the Academy of Management Journal in 1978.

134. Jain, Harish C., Neil Hood and Steve Young, "Cross-Cultural Aspects of Personnel Policies in Multi-Nationals: A Case Study of Chrysler UK", June, 1977.

135. Aivazian, V. and J.L. Callen, "Investment, Market Structure and the Cost of Capital", July, 1977. 
136. Adams, R.J., "Canadian Industrial Relations and the German Example", October, 1977.

137. Callen, J.L., "Production, Efficiency and Welfare in the U.S. Natural Gas Transmission Industry", October, 1977.

138. Richardson, A.W. and Wesolowsky, G.0., "Cost-Volume-Profit Aralysis and the Value of Information", November, 1977.

139. Jain, Harish C., "Labour Market Problems of Native People in Ontario", December, 1977.

140. Gordon, M.J. and L.I. Gould, "The Cost of Equity Capital: A Reconsideration", January, 1978.

141. Gordon, M.J. and L.I. Gould, "The Cost of Equity Capital with Personal Income Taxes and Flotation Costs", January, 1978.

142. Adams, R.J., "Dunlop After Two Decades: Systems Theory as a Framework For Organizing the Field of Industrial Relations", January, 1978.

143. Agarwa1, N.C. and Jain, H.C., "Pay Discrimination Against Women in Canada: Issues and Policies", February, 1978.

144. Jain, H.C. and Sloane, P.J., "Race; Sex and Minority Group Discrimination Legislation in North America and Britain", March, 1978.

145. Agarwal, N.C., "A Labour Market Analysis of Executive Earnings", June, 1978.

146. Jain, H.C. and Young, A., "Racial Discrimination in the U.K. Labour Market: Theory and Evidence", June, 1978.

147. Yagil, J., "On Alternative Methods of Treating Risk," September, 1978.

148. Jain, H.C., "Attitudes toward Communication System: A Comparison of Anglophone and Francophone Hospital Employees," September, 1978.

149. Ross, R., "Marketing Through the Japanese Distribution System", November, 1978.

150. Gould, Lawrence I. and Stanley N. Laiken, "Dividends vs. Capital Gains Under Share Redemptions," December, 1978.

151. Gould, Lawrence I. and Stanley N. Laiken, "The Impact of General Averaging on Income Realization Decisions: A Caveat on Tax Deferral," December, 1978.

152. Jain, Harish C., Jacques Normand and Rabindra N. Kanungo, "Job Motivation of Canadian Anglophone and Francophone Hospital Employees, April, 1979.

153. Stidsen, Bent, "Communications Relations", April, 1979.

154. Szendrovits, A.Z. and Drezner, Zvi, "Optimizing N-Stage Production/ Inventory Systems by Transporting Different Numbers of Equal-Sized Batches at Various Stages", April, 1979. 
155. Truscott, W.G., "Allocation Analysis of a Dynamic Distribution Problem", June, 1979.

156. Hanna, J.R., "Measuring Capital and Income", November, 1979.

157. Deal, K.R., "Numerical Solution and Multiple Scenario Investigation of Linear Quadratic Differential Games", November, 1979.

158. Hanna, J.R., "Professional Accounting Education in Canada: Problems and Prospects", November, 1979.

159. Adams, R.J., "Towards a More Competent Labor Force: A Training Levy Scheme for Canada", December, 1979.

160. Jain, H.C., "Management of Human Resources and Productivity", February, 1980.

161. Wensley, A., "The Efficiency of Canadian Foreign Exchange Markets", February, 1980.

162. Tihanyi, E., "The Market Valuation of Deferred Taxes", March, 1980.

163. Meadows, I.S., "Quality of Working Life: Progress, Problems and Prospects", March, 1980.

164. Szendrovits, A.Z., "The Effect of Numbers of Stages on Multi-Stage Production/Inventory Models - An Empirical Study", April, 1980.

165. Laiken, S.N., "Current Action to Lower Future Taxes: General Averaging and Anticipated Income Models", April, 1980.

166. Love, R.F., "Hu11 Properties in Location Problems", April, 1980.

167. Jain, H.C., "Disadvantaged Groups on the Labour Market", May, 1980.

168. Adams, R.J., "Training in Canadian Industry: Research Theory and Policy Implications", June, 1980.

169. Joyner, R.C., "Application of Process Theories to Teaching Unstructured Managerial Decision Making", August, 1980.

170. Love, R.F., "A Stopping Rule for Facilities Location Algorithms", September, 1980.

171. Abad, Prakash L., "An Optimal Control Approach to Marketing - Production Planning", October, 1980.

172. Abad, Prakash L., "Decentralized Planning With An Interdependent Marketing-Production System", October, 1980.

173. Adams, R.J., "Industrial Relations Systems in Europe and North America", October, 1980. 
174. Gaa, James C., "The Role of Central Rulemaking In Corporate Financial Reporting", February, 1981.

175. Adams, Roy J., "A Theory of Employer Attitudes and Behaviour Towards Trade Unions In Western Europe and North America", February, 1981.

176. Love, Robert F. and Jsun Y. Wong, "A 0-1 Linear Program To Minimize Interaction Cost In Scheduling", May, 1981.

177. Jain, Harish, "Employment and Pay Discrimination in Canada: Theories, Evidence and Policies", June, 1981.

178. Basu, S., "Market Reaction to Accounting Policy Deliberation: The Inflation Accounting Case Revisited", June, 1981.

179. Basu, S., "Risk Information and Financial Lease Disclosures: Some Empirical Evidence", June, 1981.

180. Basu, S., "The Relationship between Earnings' Yield, Market Value and Return for NYSE Common Stocks: Further Evidence", September, 1981

181. Jain, H.C., "Race and Sex Discrimination in Employment in Canada: Theories, evidence and policies",. July 1981.

182. Jain, H.C., "Cross Cultural Management of Human Resources and the Multinational Corporations", October 1981.

183. Meadows, Ian, "Work System Characteristics and Employee Responses: An Exploratory Study", October, 1981.

184. Svi Drezner, Szendrovits, Andrew Z., Wesolowsky, George 0. "Multi-stage Production with Variable Lot Sizes and Transportation of Partial Lots", January, 1982.

185. Basu, S., "Residual Risk, Firm Size and Returns for NYSE Common Stocks: Some Empirical Evidence", February, 1982.

186. Jain, Harish C. and Muthuchidambram, S. "The Ontario Human Rights Code: An Analysis of the Public Policy Through Selected Cases of Discrimination In Employment", March, 1982.

187. Love Robert F., Dowling, Paul D., "Optimal Weighted $\ell_{p}$ Norm Parameters For Facilities Layout Distance Characterizations", April, 1982.

188. Steiner, G., "Single Machine Scheduling with Precedence Constraints of Dimension 2", June, 1982.

189. Torrance, G.W. "Application of Multi-Attribute Utility Theory To Measure Social Preferences For Health States", June, 1982. 
190.

191.

192.

193.

194.

195.

196.

197.

198.

199.

200.

201.

202.

203.

204.

205.

206.

Adams, Roy J., "Competing Paradigms in Industrial Relations", Apri1, 1982.

Callen, J.L., Kwan, C.C.Y., and Yip, P.C.Y., "Efficiency of Foreign Exchange Markets: An Empirical Study Using Maximum Entropy Spectral Analysis." July, 1982.

Kwan, C.C.Y., "Portfolio Analysis Using Single Index, Multi-Index, and Constant Correlation Models: A Unified Treatment." July, 1982

Rose, Joseph B., "The Building Trades - Canadian Labour Congress Dispute", September, 1982

Gould, Lawrence I., and Laiken, Stanley N., "Investment Considerations in a Depreciation-Based Tax Shelter: A Comparative Approach". November 1982.

Gould, Lawrence I., and Laiken, Stanley N., "An Analysis of Multi-Period After-Tax Rates of Return on Investment". November 1982 .

Gould, Lawrence I., and Laiken, Stanley N., "Effects of the Investment Income Deduction on the Comparison of Investment Returns". November 1982 .

G. John Miltenburg, "Allocating a Replenishment Order Among a Family of Items", January 1983.

Elko J. Kleinschmidt and Robert G. Cooper, "The Impact of Export Strategy on Export Sales Performance". January 1983.

Elko J. Kleinschmidt, "Explanatory Factors in the Export Performance of Canadian Electronics Firms: An Empirical Analysis". January 1983.

Joseph B. Rose, "Growth Patterns of Public Sector Unions", February 1983.

Adams, R. J., "The Unorganized: A Rising Force?", April 1983.

Jack S.K. Chang, "Option Pricing - Valuing Derived Claims in Incomplete Security Markets", April 1983.

N.P. Archer, "Efficiency, Effectiveness and Profitability: An Interaction Mode1", May 1983.

Harish Jain and Victor Murray, "Why The Human Resources Management Function Fails", June 1983.

Harish C. Jain and Peter J. Sloane, "The Impact of Recession on Equal Opportunities for Minorities \& Women in The United States, Canada and Britain", June 1983.

Joseph B. Rose, "Employer Accreditation: A Retrospective", June 1983. 
207. Min Basadur and Carl T. Finkbeiner, "Identifying Attitudinal Factors Related to Ideation in Creative Problem Solving", June 1983.

208. Min Basadur and Carl T. Finkbeiner, "Measuring Preference for Ideation in Creative Problem Solving", June 1983.

209. George Steiner, "Sequencing on Single Machine with General Precedence Constraints - The Job Module Algorithm", June 1983.

210. Varouj A. Aivazian, Jeffrey L. Callen, Itzhak Krinsky and Clarence C.Y. Kwan, "The Demand for Risky Financial Assets by the U.S. Household Sector", July 1983.

211. Clarence C.Y. Kwan and Patrick C.Y. Yip, "Optimal Portfolio Selection with Upper Bounds for Individual Securities", July 1983. 


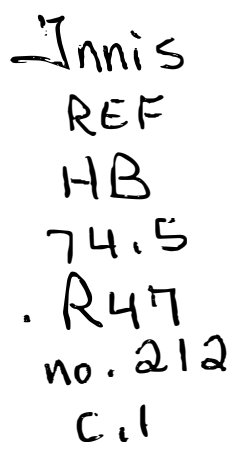

